\title{
EXPERIMENTAL INVESTIGATION OF PERFORMANCE AND EMISSION OF CI ENGINE USING ADDITIVES-FUEL
}

\author{
Suvanjan Bhattacharyya \\ Mechanical Engineering Department \\ MCKV Institute of Engineering, \\ Howrah-711204,India. \\ Email Id-suvanjanr@gmail.com
}

\author{
Dipak Kumar Seth, Soumik ,Ghosh, Sourav Pal \\ Mechanical Engineering Department \\ Modern Institute of Engineering \& Techonology \\ Bandel -712123,India \\ Email Id-dipakkumarseth13@gmail.com
}

\begin{abstract}
CI engines are very important and famous from the time of their invention; most of the automobiles are run by these engines. In this study, the effect of peanut oil blends with diesel is investigated experimentally and the performance and exhaust emission are recorded. Peanut oil and its $10 \%, 15 \%$, $20 \%, 25 \%$ blends with diesel are investigated and compared with standard diesel. Experiments were conducted at constant speed of $1200 \mathrm{rpm}$, full load and at compression ratios of 12.5:1, 15:1, 17.5:1, 20:1 and 22.5:1. The effects of compression ratio on brake power, mechanical efficiency, indicated mean effective pressure and emission characteristics has been investigated and discussed. Comparative measures of $\mathrm{CO}$, $\mathrm{NOx}$ and $\mathrm{CO}$ have been presented and discussed. Exhaust gas temperature is very much low for all the blends compared to standard diesel. Increase in compression ratio improves fuel efficiency and power output. The novelty in this work is to permit 4-stroke CI engine manufacturer to change the compression ratio.
\end{abstract}

Key Words - CI engine, compression ratio, peanut oil, NOx, emission

\section{INTRODUCTION}

Biodiesel (Peanut Oil) is an alternative fuel for compression ignition (CI) engines to minimize the supply of world crude oil in addition to being reported as an environmentally friendly fuel [1]. However, current peanut oil has some physical properties than diesel fuel such as higher viscosity,

and also density as well as lower volatility [2]. Combine of such properties to make the oil less evaporate, and mix with air during fuel injection period resulting in lower combustion efficiency compared to a similar CI engine using diesel.

Consequently, CI engine run with peanut oil produces lower engine performance [3-5]. So, now a day's long duration engine test results reported duration problems with only vegetable oils because of deposit formation, carbon build up and lubricating oil contamination [3-5]. Thus it was concluded that vegetable oils must be added or blended with diesel fuels to prevent engine failures [6-9]. Blending may reduces these problems. Heating of vegetable oils may improve the volatility of the vegetable oils, but its molecular structure remains unchanged. On the basis of experimental investigations, it has been found that converting vegetable oils into esters is an effective way to overcome all the problems associated withvegetable oils [10-14].

\section{EXPERIMENTAL SET UP}

Fig. 1 shows the experimental set up. The test engine used is a variable compression ratio fuel engine coupled with eddy current dynamometer. The specification of the engine is shown in Table 1. The piezoelectric pressure transducer and a crank angle encoder which measures the combustion pressure and the corresponding crank angle respectively are mounted into the engine head. The pressure transmitter contains a piezoelectric sensor and an integrated charge amplifier. The output shaft of the eddy current dynamometer is fixed to a strain gauge type load cell for measuring applied load to the engine.

The engine is coupled to an eddy current dynamometer to measure power. The fuel consumption was measured on mass consumption basis. The clearance volume is found by measuring the length of the pin projected into the combustion chamber. The experiments are carried out at different compression ratios 12.5, 15.0, 17.5, 20.0 and 22.5. The load is varied from no load to full load for each compression ratio at different speed of the engine. The variation of total fuel consumption, engine power and the mileage of engine are studied at different speed of the engine.

$$
\mathrm{C} . \mathrm{R}=(\mathrm{S} . \mathrm{V}+\mathrm{C} . \mathrm{V}) /(\mathrm{C} . \mathrm{V})
$$

Where,

S.V. $=$ Swept volume $=\pi \times(\text { Radius of Bore })^{2} \times$ Stroke

C.V. $=$ Clearance volume $=$ H.V. + D.C.V. + G.V. - E.D.V. 
Where,

H.V. = Head Volume

D.C.V. $=$ Deck Clearance Volume $=\pi \times(\text { Radius of bore })^{2} \times$ Deck clearance

G.V. $=$ Gasket Volume $=\pi \times(\text { Radius of bore })^{2} \times$ gasket thickness .

TABLE 1: Specification of the engine.

\begin{tabular}{|c|c|}
\hline MODEL & $\begin{array}{c}\text { E683 TCI WATER } \\
\text { COOLED }\end{array}$ \\
\hline TYPE & $\begin{array}{c}\text { 6 CYLINDER, 4-STROKE } \\
\text { DIESEL ENGINE }\end{array}$ \\
\hline $\begin{array}{c}\text { COMBUSTION } \\
\text { CHAMBER }\end{array}$ & DIRECT INJECTION \\
\hline VALVE MECHANISM & OVERHEAD VALVE \\
\hline CYLINDER BORE $\times$ & $100 \times 105(\mathrm{~mm})$ \\
STROKE & 4948 C.C. \\
\hline TOTAL DISPLACEMENT & $17.5: 1$ \\
\hline COMPRESION RATIO & REVERSE \\
\hline No. of GEARS & 6 FORWARDED AND 1 \\
\hline GEAR RATIO & 17 LIT. \\
\hline SPEEDOMETER & 1000-1300 RPM \\
\hline COOLANT CAPACITY & MULTI HOLE TYPE \\
\hline IDLING SPEED & \\
\hline TNJECTION NOZZEL &
\end{tabular}

TABLE 2: The accuracies of the measurements and the uncertainty of the calculated results.

\begin{tabular}{|c|c|}
\hline Measurements & Accuracy \\
\hline Engine speed & $\pm 5 \mathrm{rpm}$ \\
\hline Temperatures & $\pm 3^{\circ} \mathrm{C}$ \\
\hline Calculated results & Uncertainty \\
\hline Power & $\pm 4 \%$ \\
\hline Specific fuel consumption & $\pm 6 \%$ \\
\hline Crank angle encoder & $\pm 0.5^{\circ} \mathrm{CA}$ \\
\hline Time & $\pm 0.5 \%$ \\
\hline
\end{tabular}

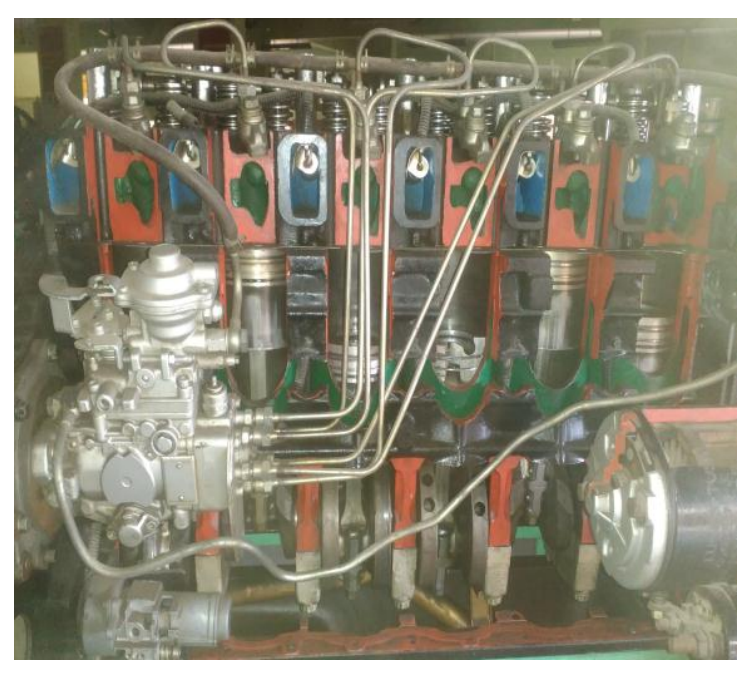

Fig. 1 Engine test rig

\section{III. . INSTRUMENTATION FOR TESTING}

Exhaust gas composition was measured using exhaust gas analyzer. The analyzer measures $\mathrm{CO}, \mathrm{HC}, \mathrm{CO}_{2}, \mathrm{O}_{2}$ and $\mathrm{NOx}$. The range and accuracy of gas analyzer is given in table 3 .

TABLE 3. Specification of Exhaust Gas Analyzer

\begin{tabular}{|c|c|c|}
\hline EXHAUST GAS & RANGE & RESOLUTIONS \\
\hline $\mathrm{CO}$ & $0-15 \%$ Volume & $0.09 \%$ Volume \\
\hline `HC & $0-17,000 \mathrm{ppm}$ & $>4500 \mathrm{ppm}$ \\
\hline $\mathrm{CO}_{2}$ & $0-25 \%$ Volume & $0.7 \%$ Volume \\
\hline $\mathrm{O}_{2}$ & $0-20 \%$ Volume & $0.5 \%$ Volume \\
\hline $\mathrm{NOx}$ & $0-6000 \mathrm{ppm}$ & $1 \mathrm{ppm}$ Volume \\
\hline
\end{tabular}

\section{RESULTS AND DISCUSSION \\ Performance and emissions characteristics}

The Fig. 2 shows the brake power (BP) with compression ratio for different additives. From this graph additives A 25\% reach greater brake power than other additives and standard diesel. Also the $\mathrm{BP}$ rises from lower compression ratio to higher ratio at full load condition. The other additives also attain high BP than diesel for all compression ratios at full load. This may be due to well upgrading of fuel spray characteristics, nice mixing of fuel-air ratio and complete combustion.

The variations of Mechanical efficiency ( $\left.\eta_{\text {mech }}\right)$ with compression ratio for different additives are shown in Fig. 3. It has been observed that the $\eta_{\text {mech }}$ of the additives is lesser at lower compression ratio and it is higher at higher compression ratio for additives $\mathrm{A} 10 \%$. The mechanical efficiency of the additives $\mathrm{A} 25 \%$ constantly increases with the increase in compression ratio when related to that of standard diesel and other additives. The maximum mechanical efficiency obtained from additives $\mathrm{A} 25 \%$ for compression ratio 17 . This is due to 


\section{Asia Pacific Journals}

better lubricity properties of additives fuels compared to diesel.

Fig. 4 shows the variation of indicated mean effective pressure (IMEP) with compression ratio for different additives. The IMEP for standard diesel is greater in low compression ratio region whereas additives $\mathrm{A} 25 \%$ and $\mathrm{A} 10 \%$ are lower at higher compression ratio than other tested additives. As a whole it was found that among all the test fuels A25\% obtain lower indicated mean effective pressure than all other tested additives at different compression ratio and full load.

The Fig. 5 shows the variation of carbon monoxide emission with different compression ratios of the different additives and diesel. Here the additives A25\% is lower than all other additives and diesel for higher compression ratio. The other additives like A10\% and A20\% also a lower amount of emission produced than diesel at different compression ratios. When compared to diesel, A25\% produced $40.02 \%$ lesser emission. The $\mathrm{CO}$ emission was decreased for all the additives than diesel due to preheating of fuel leads to the improvement in spray characteristics and better air-fuel mixing.

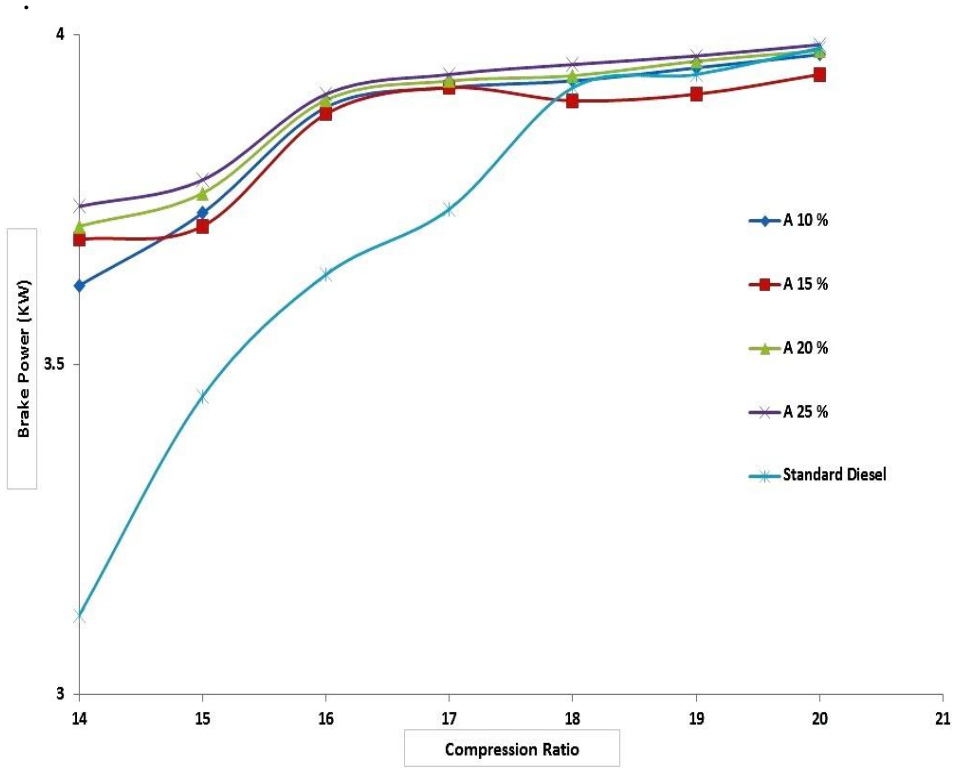

Fig. 2. Variation of break power with compression ratio for different additives

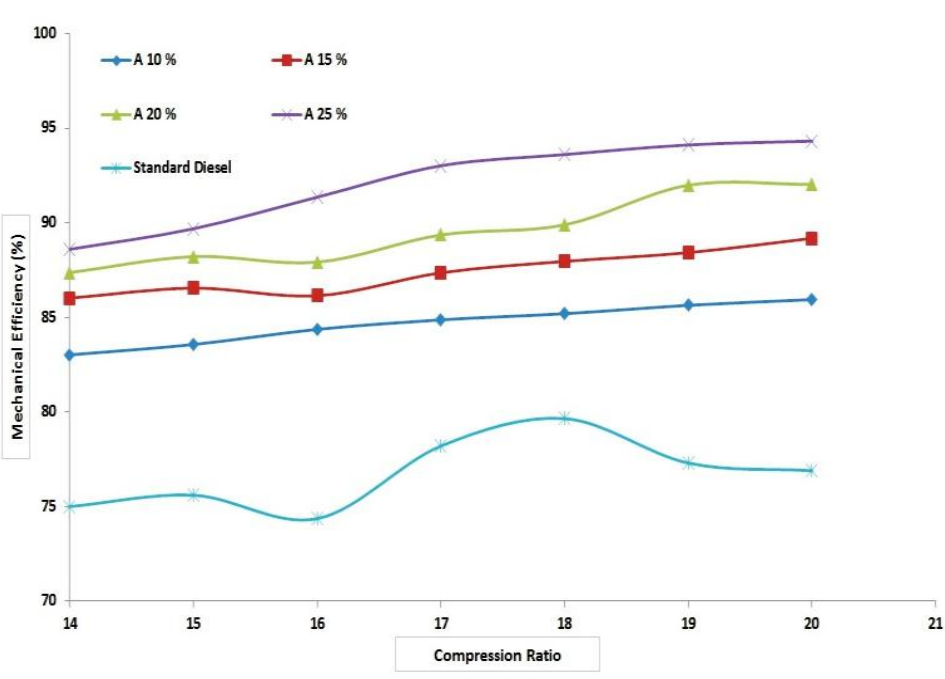

Fig. 3. Variation of Mechanical Efficiency with compression ratio for different additives

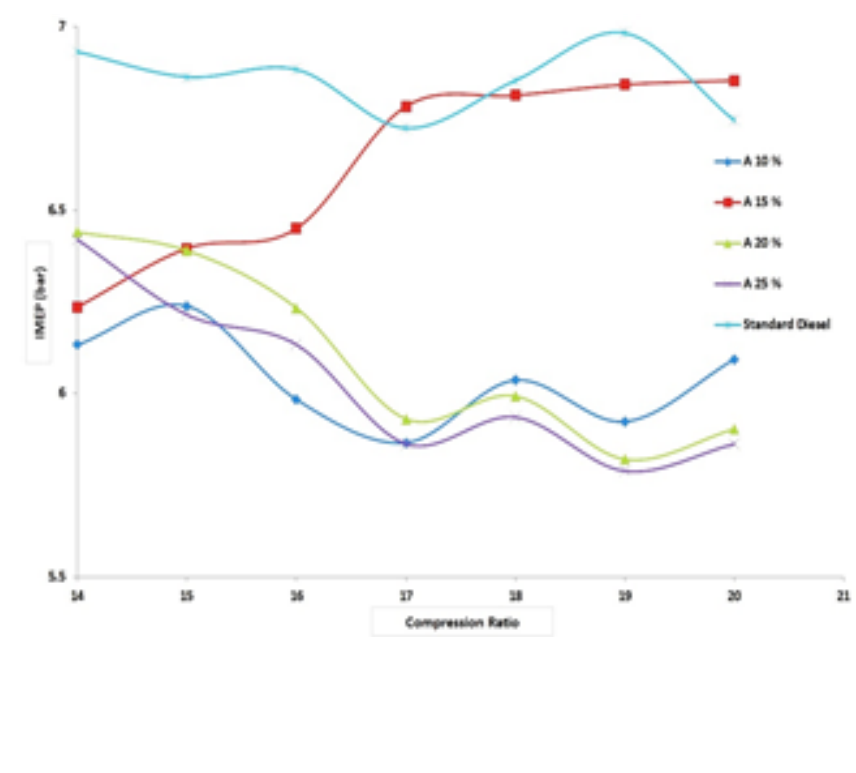

Fig.4. Variation of IMEP with compression ratio for different additives 


\section{Asia Pacific Journals}

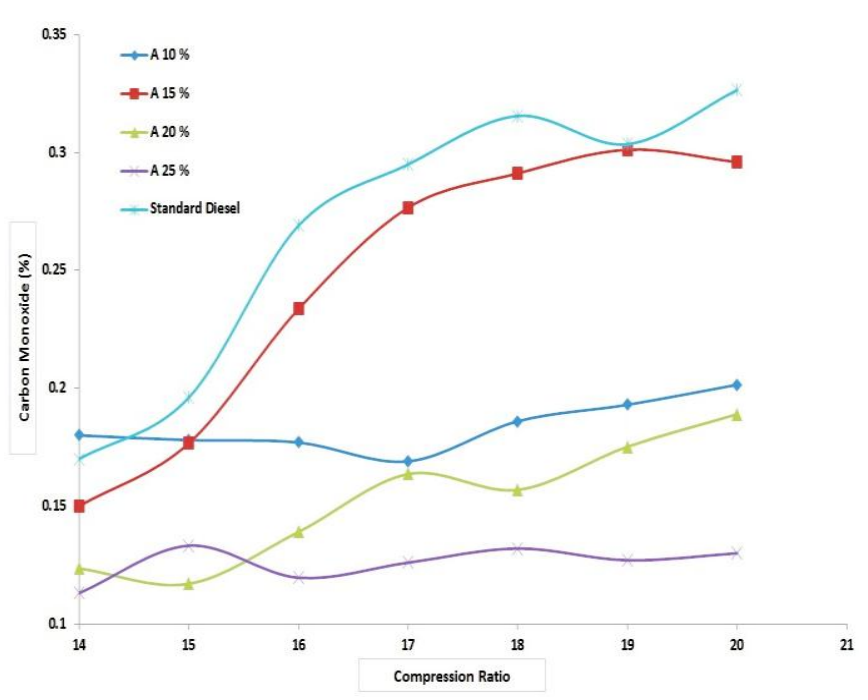

Fig.5. Variation of carbon monoxide with compression ratio for different additives

\section{CONCLUSIONS}

The significant conclusions from the present work are summarized as follows.

The performance, emission and combustion characteristics of a peanut oil mixture, kerosene, mustard oil variable compression ratio engine have been investigated and compared with that of standard diesel. The compression ratio and engine speed is varied. The total fuel consumption increased with the compression ratio. The specific fuel consumption reduced with compression ratio. The power of an engine increased with the compression ratio. The fuel efficiency increased with compression ratio.

The hydrocarbon emission of various fuels is higher at higher compression ratios. The emission of oxides of nitrogen (NOx) from the peanut oil is very close than that of diesel. The $\mathrm{CO} 2$ emission is also very close at the same conditions.

From the above observations, it has been found that the performance of the peanut oil mixture is superior when compared with the conventional standard diesel at compression ratio 17 to 20 . There is slight increase in NOx emission, but it is still comparable with that of standard diesel fuel and is also in the acceptable range.

\section{References}

[1] Rizwanul Fattah IM, Masjuki HH, Liaquat AM, Ramli R, Kalam MA, Riazuddin VN. Impact of various biodiesel fuels obtained from edible and non-edible oils on engine exhaust gas and noise emissions. Renew Sustain Energy Rev 2013;18: 552-67.

[2] Yaakob Z, Mohammad M, Alherbawi M, Alam Z, Sopian K. Overview of the production of biodiesel from waste cooking oil. Renew Sustain Energy Rev 2013;18: 184-93.
[3] Swaminathan C, Sarangan J. Performance and exhaust emission characteristics of a CI engine fueled with biodiesel (fish oil) with DEE as additive. Biomass Bio-energy 2012;39: 168-74.

[4] Jaichandar S, Annamalai K. Effects of open combustion chamber geometries on the performance of pongamia biodiesel in a DI diesel engine. Fuel 2012.

[5] Bari S, Roy MM. Prospect of rice bran oil as alternative to diesel fuel. In: Fifth international conference on small engines, their fuels and the environment; 1995. p. 31-6.

[6] Babu AK, Devaradjane G. Vegetable oils and their derivatives as fuel for CI engines - an overview. SAE 2003-01-0767.

[7] Ramdas AS, Jayaraj S, Muraleedharan C. Use of vegetable oils as IC engine fuel - a review. Renew Energy 2004;29: 727-42

[8] Huang Jincheng, Wang Yaodong, Li Shuangding, Hongdong Anthony P. Experimental investigation on the performance of a diesel engine fuelled with ethanol-diesel blends. Appl Therm Eng 2009;29: 2484-90.

[9] Hazar Hanbey, Aydin Huseyin. Performance and emission evaluation of a CI engine fuelled with preheated raw rapeseed oil (RRO)-diesel blends. Appl Energy 2010;87: 786-90.

[10] Balat Mustafa, Balat Havva. Progress in biodiesel processing. Appl Energy 2010;87: 1661-9.

[11] Rao T Venkateshwara, Rao G Prabhakar, Reddy K Hema Chandra. Experimental investigation of pongamia, Jatropha, Neem methyl esters as biodiesel in CI engine. JJMIE 2008;2: 117-22.

[12] Suresh Kumar, Velraj R, Ganesan R. Performance and emissions of a C.I engine fuelled with PPME and its blends with diesel. Renew Energy 2008;82: 1311-25.

[13] Agarwal Avinash Kumar, Rajamanoharan K. Experimental investigations of performance and emissions of Karanja oil and its blends in a single cylinder agricultural diesel engine. Appl Energy 2009;86: 106-12.

[14] Qi DH, Chen H, Geng LM, Bian YZH, Ren XCH. Performance and emission characteristics of a biodiesel-diesel-methanol blend fuelled engine. Appl Energy 2010;87: 1679-8 